\title{
Ras-dependent apoptosis correlates with persistent activation of stress-activated protein kinases and induction of isoform(s) of Bcl-x
}

\author{
Ker $\mathrm{Yu}^{1,2,3}$, Ying-Nan P. Chen ${ }^{1}$, Christina P. Ravera ${ }^{1}$, \\ William Bayona ${ }^{1}$, Carlo M. Nalin ${ }^{1}$ and Robert Mallon ${ }^{1,2}$ \\ ${ }^{1}$ Oncology Research Program, Preclinical Research, Sandoz Pharmaceuticals \\ Corporation, East Hanover, NJ 07936, USA \\ 2 Present address: Department of Oncology/Immunology, Wyeth-Ayerst \\ Research, 401 N. Middletown Road, Pearl River, NY 10965 \\ 3 corresponding author: Department of Oncology/Immunology, Wyeth-Ayerst \\ Research. Bldg. 200/4, 401 N. Middletown Road, Pearl River, NY 10965. \\ tel: 914-732-4814; fax: 914-732-5557
}

Received 7.5.97; revised 12.6.97; accepted 14.7.97

Edited by B.A. Osborne

\begin{abstract}
Ras proteins are signal transducers for many cellular responses. However, it is not well established whether Rassignaling also contributes to apoptosis. We have constructed H-Ras ${ }^{\text {R12 }}$-transformed Rat1 fibroblasts using tetracycline operator/repressor (TetO/TetR)-based conditional vectors. Rat1/TetO-Ras ${ }^{\mathrm{R} 12}$ (Rat1-Ras) cells produced high levels of $\mathrm{H}$ Ras $^{\text {R12 }}$ protein and exhibited oncogenic transformation. Treatment of Rat1-Ras cells with $0.1 \%$ serum triggered massive apoptosis. Rat1-Ras cells expressed increased basal activities of extracellular response kinase (ERK) and p46/p54 stress-activated protein kinase/c-Jun $\mathrm{NH}_{2}$-terminal kinase (SAPK/JNK). Interestingly, Ras-dependent apoptosis correlated with further persistent activation of both p46 and p54 SAPK/JNK and concurrent inhibition of ERK. Differential modulation of SAPK/JNK and ERK was not detected in tetracycline-treated cells that did not commit apoptosis. Furthermore, two $\mathrm{Bcl}-\mathrm{x}$ related proteins of $15 \mathrm{kDa}$ and $18 \mathrm{kDa}$ were highly induced in apoptotic Rat1-Ras cells. Our results establish a direct role for Ras in apoptosis, and suggest a functional relationship between H-Ras, SAPK/JNK, ERK and Bcl-x in regulating apoptosis.
\end{abstract}

Keywords: Ras; apoptosis; SAPK/JNK; Bcl-x

Abbreviations: TNF- $\alpha$, tumor necrosis factor- $\alpha$; MAPK, mitogen-activated protein kinase; SAPK/JNK, stress-activated protein kinase/c-Jun $\mathrm{NH}_{2}$-terminal kinase; ERK, mitogen-activated/extracellular response kinase; MEK, mitogenactivated/extracellular response kinase kinase; SEK, stressactivated protein kinase kinase; MEKK, mitogen-activated/ extracellular response kinase kinase kinase; H-Ras ${ }^{R 12}$, HaRas position 12 arginine mutation; TetO, tetracycline operator; TetR, tetracycline repressor; DMEM, Dulbecco's modified Eagle's medium; PBS, phosphate buffered saline; SDS-
PAGE, sodium dodecyl sulfate-polyacrylamide gel electrophoresis; GST, glutathione-S-transferase; NGF, nerve growth factor

\section{Introduction}

Recent investigations suggest that there is an integrated coregulation of proliferative and apoptotic signal transduction pathways. This conclusion is based on the observations that several oncogenes can influence the cellular processes that govern both proliferation and death. For example, overexpression of the $\mathrm{c}-M y c(M y c)$ gene in untransformed fibroblasts or T-lymphocytes causes increased cell proliferation and transformation; however, cells overexpressing $M y c$ also exhibit an increased susceptibility to apoptosis in response to serum starvation or growth factor withdrawal (Marcu et al, 1992; Evan et al, 1992; Shi et al, 1992). Similarly, overexpression of cellular E2F-1 (Qin et al, 1994; Wu et al, 1994) or viral E1A (Debbas and White, 1993; Lowe and Ruley, 1993) promotes forced cell cycle entry and apoptosis in serum-starved cells. Thus, these oncogene products can cause either mitosis or apoptosis, depending on the availability of critical growth stimuli. By contrast, the Bcl-2 protooncogene functions as a repressor of apoptosis (Tsujimoto et al, 1985; Korsmeyer, 1992). Elevated expression of $\mathrm{Bcl}-2$ in tumor cells contributes to neoplastic cell expansion by preventing normal cell turnover due to apoptosis, rather than by accelerating the rate of cell proliferation (Vaux et al, 1988; Reed, 1994). Molecular cloning of homologous $\mathrm{Bcl}-2$ genes has led to the identification of several additional family members. Among these, the Bcl-x (Boise et al, 1993) and Bax (Oltvai et al, 1993) genes are best characterized. The $B c /-x$ gene produces two distinct proteins $\left(\mathrm{Bcl}-\mathrm{x}_{\mathrm{L}}\right.$ and $\left.\mathrm{Bcl}-\mathrm{x}_{\mathrm{S}}\right)$ as a result of alternative RNA splicing (Boise et al, 1993). While Bcl- $x_{L}$ has a similar death inhibition function as $\mathrm{Bcl}-2$, Bcl- $\mathrm{x}_{\mathrm{S}}$ and $\mathrm{Bax}$ both promote apoptosis (Boise et al, 1993; Oltvai et al, 1993).

The mammalian Ras family of small guanine-nucleotidebinding proteins are conserved cellular signal transducers. Genetic mutations that cause Ras to be constitutively activated have been found in many types of human cancer, as well as in experimental tumors induced by various carcinogens (Barbacid, 1990; Bos, 1989). Ras-mediated signaling pathways are critical for a wide array of mitogenic and differentiation responses stimulated by growth factors and hormones (Barbacid, 1987; Greenwald and Rubbin, 1992; McCormick, 1995). Recent studies suggest that Ras may also be important in the regulation of cellular survival or death. In support of its role in cell survival, overexpression of activated Ras gene in hematopoietic cells leads to suppression of apoptosis (Kinoshita et al, 1995; 
Terada et al, 1995). Activated H-Ras also suppresses apoptosis in intestinal epithelial cells grown in suspension (Rak et al, 1995). In contrast, two studies have shown that ectopic expression of oncogenic $H$-Ras in murine fibroblasts confers susceptibility to apoptosis caused by serum starvation (Tanaka et al, 1994) or exposure to TNF- $\alpha$ (Fernandez et al, 1994). Effects on cell death have also been described for other Ras related proteins such as RRas (Wang et al, 1995) and Rho (Jimenez et al, 1995). In a recent report Kauffmann et al (1997) showed that activated Ras can also enhance apoptosis triggered by c-Myc. These authors further suggested that Ras-signaling may lead to activation of separate $\mathrm{PI}(3)$ kinase pathway and Raf1 pathway, which may have opposing effects on cell survival and death. Taken together, despite different outcomes were observed from different cellular systems, it seems likely that both cell death and survival may ultimately depend on a balance between multiple pathways linked to Ras (Tanaka 1994; Chen and Faller, 1995; Kauffmann et al, 1997).

Ras-signaling pathways are mediated in part through two parallel serine/threonine mitogen activated protein kinases (MAPKs) pathways (Karin, 1995). In addition to the RafMEK-ERK cascade required for cell growth and differentiation, a second MAP kinase pathway termed the stress activated protein kinase/c-Jun N-terminal kinase (SAPK/ JNK) cascade has recently been identified. Signaling through the MEKK-SEK1-SAPK/JNK cascade can be activated in response to mitogens and several stress stimuli and have diverse effects on cell growth (Hibi et al, 1993; Derijard et al, 1994; Kyriakis et al, 1994; Han et al, 1994). Similar to the ERK MAP kinases, activation of SAPK/JNK requires dual phosphorylation on conserved threonine and tyrosine residues (Cobb and Goldsmith, 1995). Because activation of SAPK/JNK can be triggered by several stimuli that cause apoptosis, studies have been directed to examine its roles in modulating apoptotic signaling pathway. Recent reports suggest that SAPK/ JNK cascade could positively influence apoptosis in response to several stress signals (Xia et al, 1995; Chen et al, 1996; Verheij et al, 1996; Cuvillier et al, 1996).

Although effects of Ras on apoptosis has been documented, the biochemical and molecular changes underlying this phenomenon are largely unknown. To examine the role of Ras and its signaling pathways in modulating apoptosis, we have constructed Rat1 fibroblast cell lines that were transformed by oncogenic H-Ras ${ }^{\mathrm{R} 12}$ using conditional expression (Gossen and Bujard, 1992). In the present study, we show that activated $\mathrm{H}-\mathrm{Ras}^{\mathrm{R} 12}$ is a potent inducer of apoptosis in response to serum starvation. Moreover, Ras-dependent apoptosis likely involves differential regulation of SAPK/JNK and ERK pathways, and induction of isoform(s) of Bcl-x.

\section{Results}

\section{Transformation of Rat1 fibroblasts by $\mathrm{H}-\mathrm{Ras}^{\mathrm{R} 12}$ using TetO/TetR conditional expression}

To create a reversible Ras-transformed cell system, we constructed an expression vector in which an activated and oncogenic human $\mathrm{H}-\mathrm{Ras}^{R 12}$ gene was placed downstream of cis-DNA elements derived from the bacterial tetracycline operator (TetO). Expression of the TetO-linked H-Ras ${ }^{R 12}$ gene required transactivation by a chimeric transcription factor TetR-VP16, which consists of the bacterial tetracycline repressor (TetR) fused to the transcriptional activation (TA) domain of a viral transcription factor VP16 (Figure 1A) (Gossen and Bujard, 1992). By cotransfection of these plasmids into Rat1 cells, we obtained several Rat1/TetO-HRas $^{\mathrm{R} 12}$ (Rat1-Ras) cell lines. In the absence of tetracycline, these cells produced high levels of $\mathrm{H}-\mathrm{Ras}^{\mathrm{R} 12}$ protein, whereas treatment with 2-5 $\mu \mathrm{M}$ tetracycline prevented expression of $H$-Ras ${ }^{R 12}$ (Figure 1B). Thus, ectopic expression of $H$-Ras ${ }^{R 12}$ in these cells could be tightly controlled by tetracycline.

Rat1-Ras cells displayed a distinct growth morphology and transformed cellular phenotype when cultured in the absence of tetracycline. Cells in monolayer culture exhibited elongated spindle-shape that attached poorly to culture plates (Figure 2A). Upon reaching confluency, these cells formed high numbers of foci due to loss of contact growth inhibition. Further confirmation of the oncogenic transformation of these cells by $\mathrm{H}-\mathrm{Ras}^{\mathrm{R} 12}$ was demonstrated by the ability of these cells to grow in an anchorageindependent manner. As shown in Figure 2B, high levels of $\mathrm{H}$-Ras ${ }^{\mathrm{R} 12}$ in these cells led to efficient colony formation and growth in soft agar. As expected, these morphological and

A



B

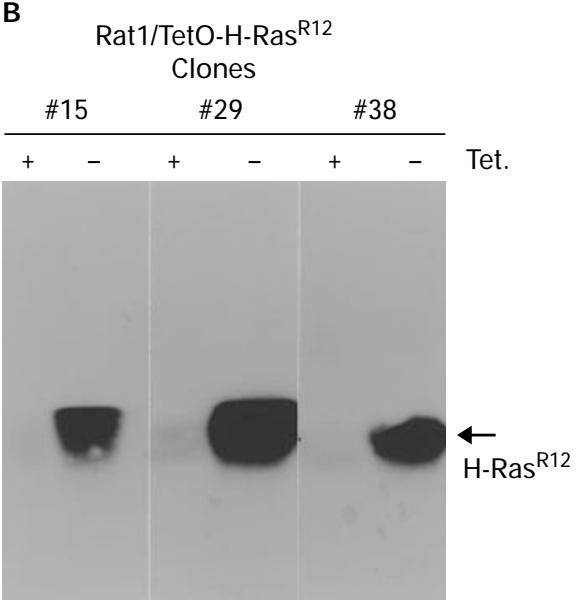

Figure 1 Transformation of Rat1 cells by conditional H-Ras overexpression (A) Schematic representation of pTetO-H-Ras ${ }^{\mathrm{R} 12}$ and pTetR-VP16/Neo constructs. pTetO-H-Ras ${ }^{R 12}$ contains the H-Ras ${ }^{R 12}$ gene placed downstream of the bacterial TetO DNA sequences. pTetR-VP16/Neo is an expression vector producing a chimeric transcription factor consisting of TetR and the transcriptional activation (TA) domain of viral VP16. (B) Tetracycline repressible expression of $H$-Ras ${ }^{R 12}$ in Rat1-Ras cells. Cell lysates were prepared from clones 15,29 , and 38 grown with or without $5 \mu \mathrm{M}$ tetracycline for 4 days. $50 \mu \mathrm{g}$ of total lysates were subjected to immunoblotting with a pan-Ras antibody as described in Materials and Methods. The arrow indicates the migration of full-length $\mathrm{H}$-Ras ${ }^{\mathrm{R} 12}$ protein 
A
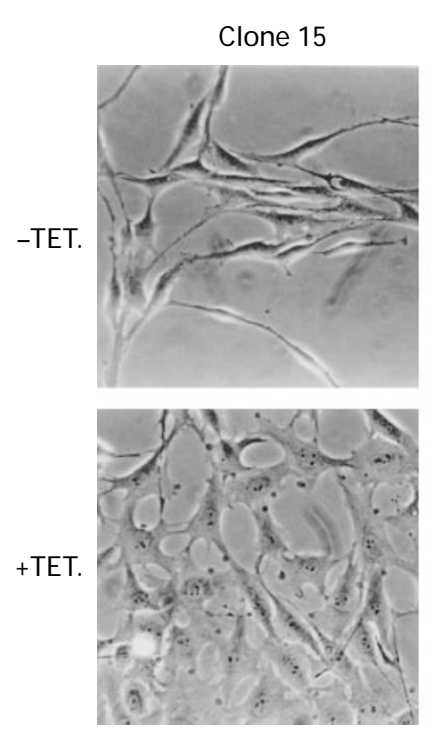

RAT1/TETO-H-RAS CLONES
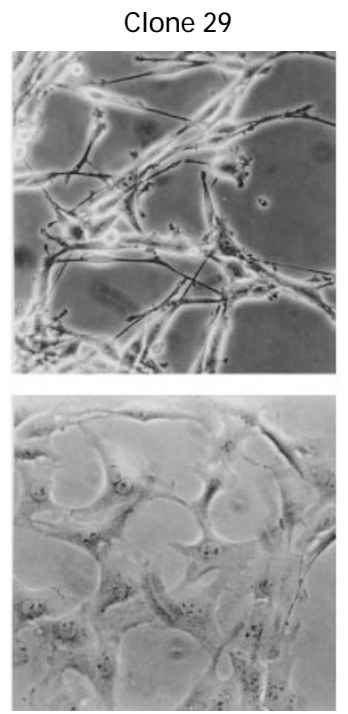

Clone 38
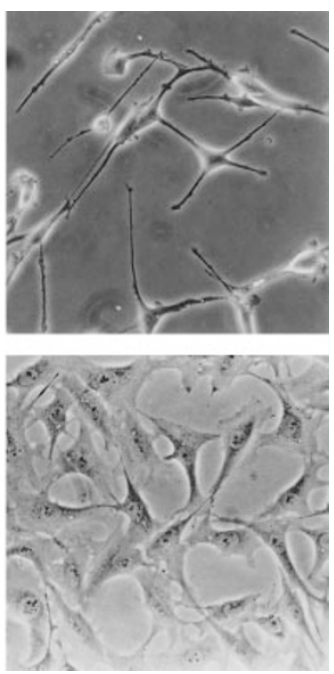

B

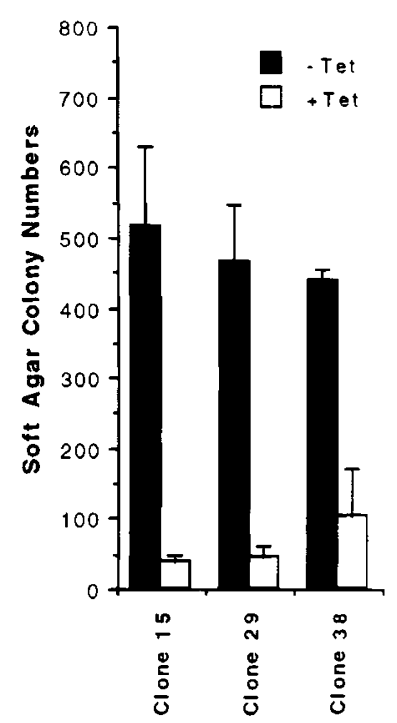

Figure 2 Morphological and cellular transformation of Rat1 cells by H-Ras ${ }^{\mathrm{R} 12}$. (A) Morphological changes in Rat1-Ras cells. Rat1-Ras cells were plated in 6-well dishes, and grown in complete media with $10 \%$ serum either in the presence or absence of tetracycline for 4 days. Total magnification: $400 \times$. (B) Anchorageindependent growth of Rat1-Ras cells. Soft agar growth experiments were performed in 24-well dishes as described in Materials and Methods. Tetracycline (10 $\mu \mathrm{M}$ ) was added to subsets of wells. After incubation for 14 days, the number of colonies in each well was determined by a computerized image analyzer. Average colony numbers were derived from $10-12$ replicate wells

\section{CLONE 15}

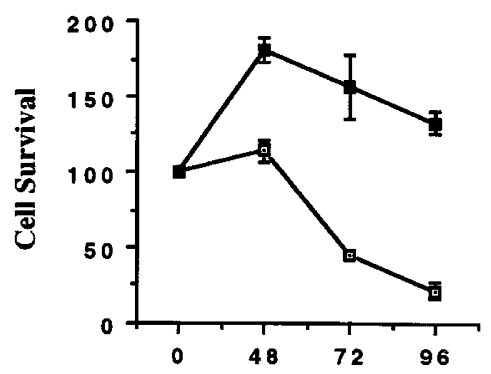

CLONE 29



CLONE 38



Figure 3 Low-serum induced cell death of Rat1-Ras cells. Rat1-Ras clones and corresponding tetracycline-treated (+Tet) cells (pretreated with tetracycline for at least 5-7 days before the initiation of experiments) were plated in 6 -well dishes in complete media with $10 \%$ serum, and then switched to media containing $0.1 \%$ serum $24 \mathrm{~h}$ later. On day 0 (the day switching to low-serum) and 2, 3 and 4 days after low-serum exposure, culture supernatants were removed, and cells were collected by trypsinization. Viable cells from each well were counted by trypan blue exclusion. Average cell numbers were derived from triplicate wells within the same experiment, and were expressed as relative percent survival compared to the cell numbers on day 0 . Data presented are averages of three independent experiments with its associated standard deviation (S.D.)

cellular changes were inhibited by addition of tetracycline (Figure $2 \mathrm{~A}$ and $\mathrm{B}$ ).

\section{H-Ras ${ }^{R 12}$-transformed Rat1 fibroblasts undergo rapid apoptosis following serum deprivation}

Further analysis of growth characteristics of Rat1-Ras cells revealed that these cells were extremely sensitive to lowserum growth conditions. Initial observations for 12 independent clones indicated that they all exhibited reduction in viability after exposure to media with $0.1 \%$ serum. Cell death caused by low-serum stress was measured in three independent clones (clones 15, 29 and 38) by trypan-blue exclusion (Figure 3). Upon serum withdrawal, all three clones showed transient small increases in cell number, followed by rapid and extensive cell death. By 72 h, $50-70 \%$ of the cells were dead relative to Day 0 (Figure 3 ), and the entire culture died within 4-5 days (not shown). Cell death was completely dependent on overexpression of $H$-Ras ${ }^{R 12}$, since death could be prevented with $2 \mu \mathrm{M}$ tetracycline prior to serum withdrawal (Figure 3). The observed cell death was not due to TetR-VP16 chimeric protein because its expression was constitutive in both tetracycline-treated and -untreated Rat1-Ras cells. Response to low-serum by Rat1-Ras cells treated with tetracycline was similar to that by parental Rat1 cells. In both these cases there was a small increase in cell numbers 
followed by growth arrest, but not cell death (Figure 3, not shown).

To examine whether Ras-dependent cell death in lowserum occurs by apoptosis, Rat1-Ras clones 29, 38 and corresponding tetracycline-treated cells were stressed by exposure to $0.1 \%$ serum for 3 days. Cells were then stained with bisbenzimide $\mathrm{H} 33258$ for microscopic examination (Figure $4 \mathrm{~A}$ ). In the presence of tetracycline, there was minimal cell death resulting from low-serum stress as indicated by only background staining of normal nuclei. In contrast, clones of Rat1-Ras cells exposed to low-serum in the absence of tetracycline showed massive cell death with large numbers of brightly stained, condensed, and fragmented nuclei (Figure 4A). Electrophoresis of genomic DNA showed nucleosomal laddering for Rat1-Ras clones in the absence of tetracycline (Figure 4B). In contrast, tetracycline-treated Rat1-Ras cells showed only low levels of random DNA degradation without distinct DNA laddering (Figure 4B). This background degradation of DNA in tetracycline-treated cells in this experiment was more noticeable in clone 29 than clone 38, which may be due to an insufficient repression of $\mathrm{H}-\mathrm{Ras}^{\mathrm{R} 12}$ under these conditions. Experiments with clone 15 showed similar result (not shown). From these studies we conclude that apoptosis is the primary mode of low-serum induced cell death in Rat1-Ras cells.

\section{Persistent activation of p46 and p54 SAPK/JNK and inhibition of ERK in Ras-dependent apoptosis}

Previous reports have suggested a potential involvement of SAPK/JNK pathway in regulating apoptosis, and it has been documented that Ras-signaling is mediated in part through ERK and SAPK/JNK members of the MAP kinase family. We
A
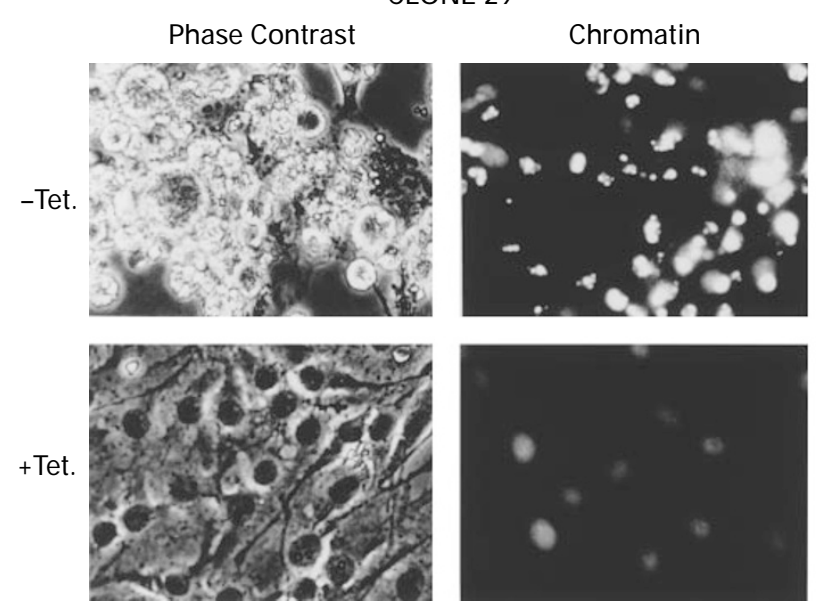

B

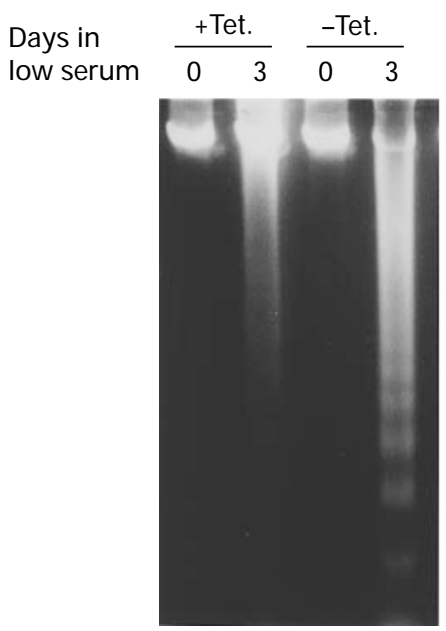

CLONE 38
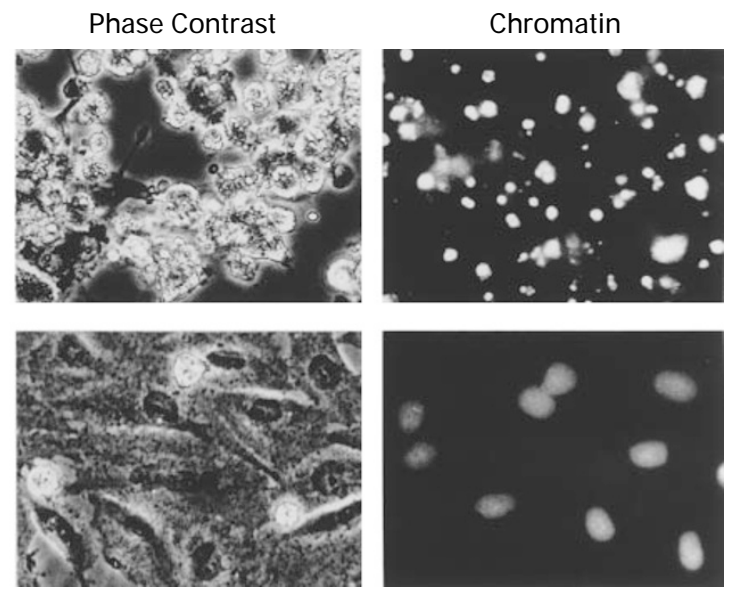

CLONE 38


Figure 4 Ras-dependent cell death by apoptosis. (A) Cells of Rat1-Ras clones 29, 38 and tetracycline-treated (+Tet) cells were plated in 6-well dishes, switched to $0.1 \%$ serum for 3 days, and then photographed. For each cell line, left panels, phase-contrast view (total magnification: $400 \times$ ); right panels, nuclear morphology after staining cells with $1 \mu \mathrm{g} / \mathrm{ml}$ bisbenzimide $\mathrm{H} 33258$ (total magnification: $400 \times$ ). Cells were incubated either without (upper panels) or with $5 \mu \mathrm{M}$ tetracycline (lower panels). (B) Genomic DNA was isolated from clones 29 and 38 either grown in 10\% serum or $0.1 \%$ serum as described in Materials and Methods. Equal amounts of total DNA were size fractionated in a $2.0 \%$ TAE-agarose gel and visualized by ethidium bromide staining 
therefore examined the potential involvement of MAPK family of protein kinases in Ras-dependent apoptosis. We measured individual kinase activity from cells that were stressed with low-serum for various times. For each time point, protein lysates were prepared from total cells (pooled from adherent and floating cells). Equal amounts of lysates were subjected to immunoprecipitation with antibodies raised against p46 SAPK/JNK, p54 SAPK/JNK, p38 MAPK and ERK. Kinase activities were then measured in an immunocomplex kinase assay with added protein substrate. The results with clone 29



B



BLOT:

C

p46 SAPK/J NK

In vivo phosphorylation


p38 MAPK
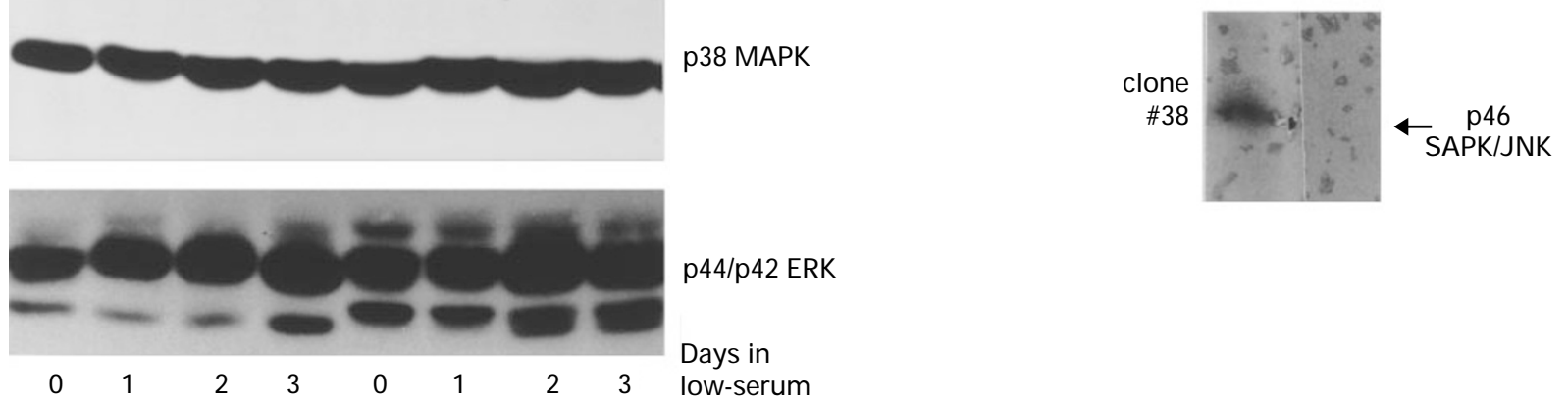

Figure 5 Activation of SAPK/JNK and inhibition of ERK during Ras-dependent apoptosis. (A) Rat1-Ras clone 29 and tetracycline-treated (+Tet) cells were plated in 6-well dishes in complete media with $10 \%$ serum, and then switched to media with $0.1 \%$ serum. Protein lysates were prepared from total cell population at indicated time points. Equal amounts of protein lysates $(200 \mu \mathrm{g})$ were subjected to immunoprecipitation with kinase-specific antibodies as described in Materials and Methods. p46/p54 SAPK/JNK, p38 MAPK and p44/p42 ERK kinase activity was measured in the immunocomplex with added $5 \mu \mathrm{g}$ recombinant substrate protein GST-c-Jun (1-79), Phas I and MBP, respectively, in the presence of [ ${ }^{32}$ P]ATP. Phosphorylation of substrate proteins was examined after SDS - PAGE by autoradiography. An autoradiograph of the gel is presented, and specific signals corresponding to active kinases were also quantitated by phosphor-imaging analyzer. (B) Lysates $(100 \mu \mathrm{g})$ prepared similarly as in (A) were subjected to immunoblotting with indicated kinase-specific antibodies to determine the kinase protein levels. (C) Rat1-Ras clones 29 and $38\left(-/+\right.$ Tet) were grown in media with $10 \%$ serum and metabolically labeled with ${ }^{32} \mathrm{P}$-phosphate before protein lysates were prepared. Equal amounts of lysates $(200 \mu \mathrm{g})$ were immunoprecipitated with p46 SAPK/JNK antibody (Sc-474). Phosphorylation of p46 SAPK/JNK was detected by autoradiography after SDS-PAGE. The arrow indicates the in vivo phosphorylated p46 SAPK/JNK, which was increased in $H$-Ras ${ }^{R 12}$-expressing cells 
(Figure 5A) indicated that Rat1-Ras cells expressed a significantly increased basal levels of active p46 SAPK/JNK and ERK compared to tetracycline-treated cells. The basal activity for p54 SAPK/JNK was also higher in $\mathrm{H}$-Ras ${ }^{R 12}$. expressing cells. Upon low-serum treatment, Rat1-Ras cells showed a further induction (fourfold) of p46 SAPK/JNK by $48 \mathrm{~h}$, followed by a decrease at $64 \mathrm{~h}$ (Figure 5A). Similarly, p54 SAPK/JNK was also highly activated in low-serum treated Rat1-Ras cells, although with a more persistent kinetics than p46. The maximal p54 activation (12-fold) was seen by $48 \mathrm{~h}$ and remained high at $64 \mathrm{~h}$ (Figure 5A). In contrast to Ras ${ }^{R 12}$. overexpressing cells, activation of p46 or p54 SAPK/JNK was not detected in tetracycline-treated Rat1-Ras cells after lowserum stress (Figure 5A). These results indicated that activation of p46 and p54 SAPK/JNK were both specific to $H$-Ras ${ }^{R 12}$-expressing cells and that peak accumulations of SAPK/JNK preceded maximal apoptosis observed between three to four days after low-serum stress (Figures 3 and 5A). Similar experiments indicated that unlike p46/p54 SAPK/JNK, activities for p38 MAPK and ERK were not induced in Rat1Ras cells following low-serum stress (Figure 5A). Rather, we observed a small but reproducible decrease (2-3-fold) in ERK activity in Rat1-Ras cells after 2-3 days in low-serum (Figure 5A, not shown). Thus, it appears that while overexpression of $H$-Ras ${ }^{R 12}$ causes increased basal levels for both SAPK/JNK and ERK, these two classes of MAPK family are regulated quite differently in Rat1-Ras cells after serum withdrawal. This pattern of differential modulation of SAPK/JNK and ERK was also observed with low-serum stressed apoptosis in Rat1-Ras clone 38 (not shown).

In parallel experiments, we performed Western blot analysis to determine the expression of these kinases. Equal amounts of lysates were fractionated in SDS-PAGE and immunoblotted with antibodies for p46 SAPK/JNK, p54 SAPK/JNK, p38 MAPK and p44/p42 ERK (Figure 5B). These experiments demonstrated that the protein levels for p46, p54 SAPK/JNKs, p38 MAPK and ERK were similar between tetracycline-treated and -untreated Rat1-Ras cells, and they remained relatively constant after treatment with low-serum. The Western blot of ERK revealed that while the level of p44/p42 ERKs remained similar among different samples, there was a basal level increase in phosphorylated forms of $\mathrm{p} 44 / \mathrm{p} 42 \mathrm{ERK}$ in Rat1-Ras cells relative to tetracycline-treated cells as indicated by reduced electrophoretic mobilities, which likely account for an elevated ERK activity in these cells (Figure 5A, $0 \mathrm{~h}$ ). Noticeably, lowserum exposure to Rat1-Ras cells caused a decrease of phosphorylated p44 and p42 ERK, which might be consistent with a reduction in kinase activity (Figure $5 \mathrm{~A}$, $48 \mathrm{~h}, 64 \mathrm{~h}$ ). To determine whether the increase of basal SAPK/JNK activity in Rat1-Ras cells was due to increased phosphorylation of SAPK/JNK itself, lysates were prepared from cells grown in $10 \%$ serum and metabolically labeled with ${ }^{32} \mathrm{P}$-phosphate. Immunoprecipitation of in vivo labeled lysates revealed that both Rat1-Ras clones 29 and 38 expressed increased basal levels of phosphorylated p46 SAPK/JNK compared to tetracycline-treated cells (Figure $5 \mathrm{C})$. Therefore, as previously proposed by others, activation of SAPK/JNK in Rat1-Ras cells likely involves upstream kinases through phosphorylation.

\section{Induction of $15 \mathrm{kDa}$ and $18 \mathrm{kDa}$ isoform(s) of $\mathrm{Bcl}-\mathrm{x}$ during apoptosis}

To further examine whether Ras-mediated apoptosis involves several previously described apoptosis modulators such as p53, Bax, and Bcl-x, we performed Western blot analysis. Cellular p53 protein level was not significantly altered in Rat1 cells after transformation by $\mathrm{H}$-Ras ${ }^{\mathrm{R} 12}$, nor was $\mathrm{p} 53$ selectively accumulated after exposure of Rat1-Ras cells to low-serum stress (not shown). However, Western blot analysis of low-serum-stressed Rat1-Ras clones showed a high induction of two closely-migrating proteins recognized by a $\mathrm{Bcl}-\mathrm{x}$ monoclonal antibody. These $\mathrm{Bcl}-\mathrm{x}$ related proteins from both clone 29 (Figure 6A) and clone 38 (not shown) had apparent molecular mass of $15 \mathrm{kDa}$ and $18 \mathrm{kDa}$, and were induced after $48 \mathrm{~h}$ of low-serum treatment. Induction of both proteins was specific to Ras-transformed cells undergoing apoptosis, since these proteins were minimally detected in tetracycline-treated cells (Figure 6A, lower panel). The $30 \mathrm{kDa}$ long form of $\mathrm{Bcl}-\mathrm{x}\left(\mathrm{Bcl}-\mathrm{x}_{\mathrm{L}}\right)$ remained relatively constant during low-serum response in these cells (Figure $6 \mathrm{~A}$, upper panel). Because the $15 \mathrm{kDa}$ and $18 \mathrm{kDa}$ proteins detected in apoptotic Rat1-Ras cells were smaller than the previously reported $\mathrm{Bcl}-\mathrm{x}_{\mathrm{S}}(21 \mathrm{kDa})$, we carried out immunoprecipitation experiments using two additional anti-Bcl-x polyclonal antibodies. As shown in Figure 6B (lanes 1 and 2), both the $15 \mathrm{kDa}$ and $18 \mathrm{kDa}$ proteins were specifically precipitated with both antibodies. Therefore, it is likely that both p15 and p18 proteins are isoform(s) of Bcl-x. Alternatively, they may be products of novel gene(s) that are highly homologous to Bcl-x.

In parallel experiments, expression of Bax protein was also examined. By immunoblot analysis, we could identify two Bax isoforms $(21 \mathrm{kDa}$ and $\sim 18 \mathrm{kDa})$, present at low levels in the tetracycline-treated Rat1-Ras cells. Overexpression of $H$-Ras ${ }^{R 12}$ in both Rat1-Ras clone 29 (Figure $6 \mathrm{C}$ ) and clone 38 (not shown) resulted in an increase of basal level expression of the $18 \mathrm{kDa}$ Bax protein. After exposure to low-serum stress, p18 Bax was found to be present at high levels in both tetracycline-treated and untreated Rat1-Ras cells, while a slower and moderate increase of p21 Bax was detected in apoptotic Rat1-Ras cells (Figure 6C).

\section{Discussion}

In the present study we have examined the effect of overexpression of oncogenic $H$-Ras ${ }^{R 12}$ in Rat1 fibroblasts on susceptibility to low-serum induced apoptosis. Using Rat1 cells with conditional expression of $H-R_{a s}{ }^{12}$, we have established a clear correlation between deregulated oncogenic $\mathrm{H}$-Ras and low-serum-induced apoptosis. Our evidence is in contrast to several reports that Ras suppresses apoptosis (Kinoshita et al, 1995; Terada et al, 1995; Rak et al, 1994). However, other studies with cellular systems more similar to ours have shown that constitutive Ras activation can promote apoptosis. Oncogenic $\mathrm{H}$-Ras causes apoptosis in murine embryo fibroblasts after serum withdrawal (Tanaka et al, 1994) and confers susceptibility to TNF- $\alpha$ induced apoptosis in 10T1/2 murine fibroblasts (Fernandez et al, 1994). 
Activated R-Ras increases apoptosis in 32D.3 murine pre-B cells in response to IL-3 removal (Wang et al, 1995). Furthermore, overexpression of wild-type Rho induces apoptosis in NIH3T3 cells following serum withdrawal (Jimenez et al, 1995). Consistent with a connection between the Ras-signaling pathway and apoptosis in vivo, p120rasGAP deficient mice display extensive neuronal apoptosis (Henkemeyer et al., 1995). The basis for differential outcomes of death or survival resulting from Ras-overexpression in cultured cell systems has not been determined, but likely depend on a balance of cellular background and multiple pathways linked to Ras-signaling (Tanaka et al, 1994; Chen and Faller, 1995; Kauffmann et al, 1997).
In Rat1-Ras cells, the effects of activated H-Ras on apoptosis were associated with the transformed cell phenotype. These cells exhibited a dramatically altered monolayer growth morphology, are capable of anchorageindependent growth, and responded to low-serum stress by inducing apoptosis. Although oncogenic $\mathrm{H}$-Ras ${ }^{R 12}$ overexpression results in both cellular transformation and elevated susceptibility to apoptosis, some downstream events leading to apoptosis are likely to be distinct from those regulating cellular proliferation and transformation. Consistent with this notion, Fernandez et al (1994) have suggested that TNF- $\alpha$ induced apoptosis in H-Rastransformed $10 \mathrm{~T} 1 / 2$ cells is not directly mediated by Ras

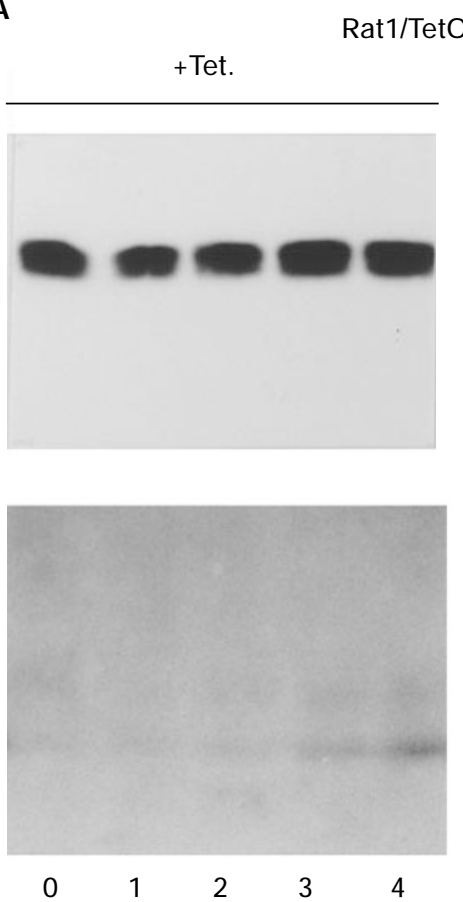

Rat1/TetO-Ras\#29

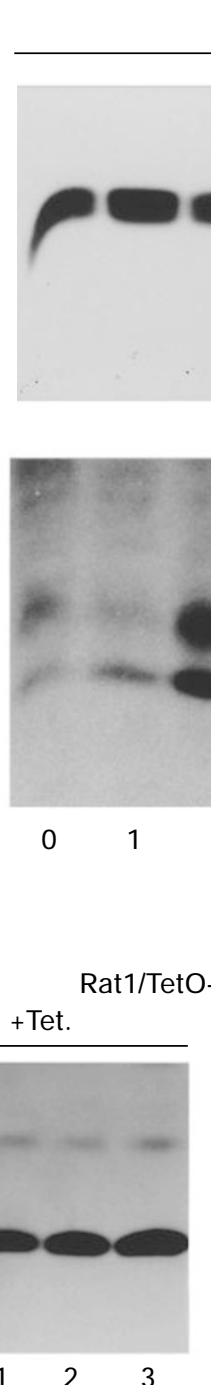

C
-Tet.

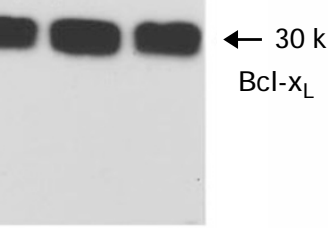

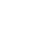

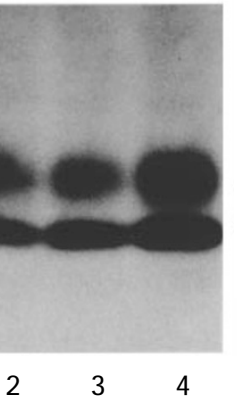

$\leftarrow 18 \mathrm{k}$

$\leftarrow 15 \mathrm{k}$

$\mathrm{BCl}-\mathrm{x}_{\mathrm{s}}$

Days in

low-serum
B

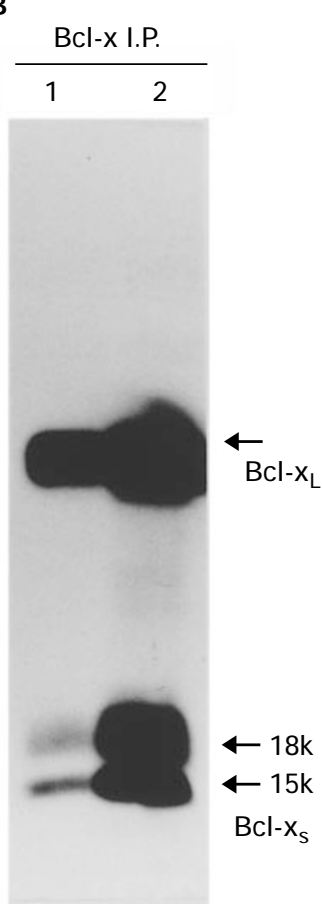

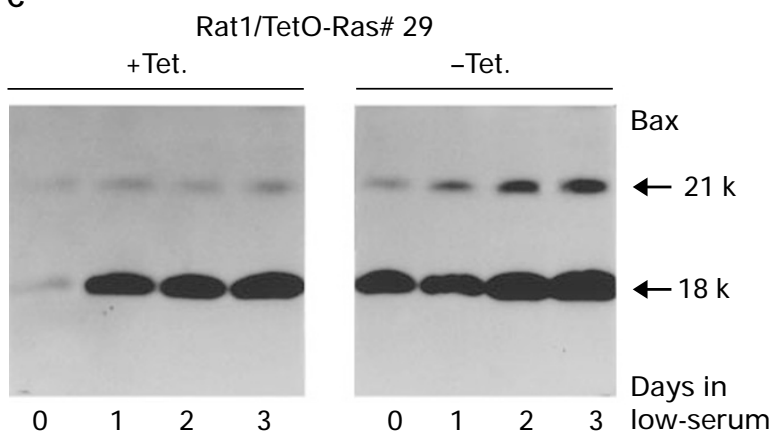

Figure 6 Induction of $\mathrm{Bcl}-\mathrm{x}_{\mathrm{s}}$ isoform(s) in Rat1-Ras cells undergoing apoptosis. (A) Cells of Rat1-Ras clone 29 and tetracycline-treated (+Tet) cells were plated in 6 -well dishes in media with $10 \%$ serum, and then switched to media with $0.1 \%$ serum. After the indicated times, cell lysates were prepared and equal amounts of total protein were subjected to immunoblotting with an anti-mouse Bcl-x monoclonal antibody as described in Materials and Methods. Arrows indicate Bcl- $\mathrm{X}_{\llcorner}$and two closely migrating $15 \mathrm{kDa}$ and $18 \mathrm{kDa} \mathrm{Bcl}-\mathrm{x}$ isoform(s). The panels of top ( 2 min exposure) and bottom ( 5 min exposure) were from the same Bcl-x Western blot. (B) Protein lysates of low-serum-treated Rat1-Ras clone 29 were immunoprecipitated with two separate anti-Bcl-x polyclonal antibodies as described in Materials and Methods. Immunoprecipitated material was then subjected to immunoblotting as described in (A). (C) Protein lysates prepared similarly as in (A) were subjected to immunoblotting with an anti-Bax antibody. Arrows indicate two $21 \mathrm{kDa}$ and $18 \mathrm{kDa}$ Bax proteins 
since TNF-resistant clones isolated from TNF-sensitive cells retained equivalent levels of Ras protein and transformed phenotype.

Rat1-Ras cells exhibited elevated basal levels of active SAPK/JNK and ERK compared to tetracycline-treated cells. However, SAPK/JNK and ERK were regulated very differently in Rat1-Ras cells after treatment with lowserum. While ERK activity was decreased after $2-3$ days of low-serum treatment, both p46 and p54 SAPK/JNK activities were significantly further induced, with peak accumulations seen approximately 2 days after low-serum stress. It was noted that although the basal activity of p54 was low, its induction by low-serum was somewhat more persistent than $\mathrm{p} 46$, which may suggest that the biochemical steps for activating p46 and p54 in low-serum treated Rat1-Ras cells are not identical. In contrast to Rat1Ras cells, exposure of tetracycline-treated Rat1-Ras cells to low-serum did not cause detectable activation of p46 or p54 SAPK/JNK.

The distinct activation pattern for SAPK/JNK in Rat1-Ras cells may contribute to the regulation of apoptosis. Although our results do not constitute a proof for functional involvement of SAPK/JNK in apoptosis, this speculation is consistent with two aspects of the apoptotic death in Rat1Ras cells. First, low-serum-induced SAPK/JNK activation only occurred in the $H$-Ras ${ }^{R 12}$-overexpresing cells undergoing apoptosis but not in tetracycline-treated Rat1-Ras cells that did not commit active cell death. Second, the maximal SAPK/JNK activity was seen approximately 2 days following low-serum stress, which occurred prior to maximal apoptosis observed between 3-4 days after low-serum stress. Thus, it is possible that selective activation of SAPK/JNK cascades may play a role in conferring cellular susceptibility to apoptosis or in the induction of active death program. Because ERK activity was decreased after lowserum stress, it is also possible that the differential activation of SAPK/JNK and concurrent inhibition of ERK may collectively contribute to the regulation of cell death. Consistent with these speculations, a recent study correlated activation of SAPK/JNK and inhibition of ERK with apoptosis in $\mathrm{PC} 12$ cells in response to NGFwithdrawal (Xia et al, 1995). SAPK/JNK activation has also been implicated in modulating apoptosis in Jurkat Tcells after exposure to lethal doses of $\gamma$ radiation (Chen et al, 1996), and in U937 monoblastic leukemia cells stressed by ceramide (Verheij et al, 1996; Cuvillier et al, 1996). To further strengthen a connection between SAPK/JNK and apoptosis, dominant-negative kinase mutants inhibit apoptosis in PC12 cells after NGF-withdrawal (Xia et al, 1995) and radiation-induced apoptosis in 293T cells (Chen et al, 1996).

Several external stress stimuli can activate SAPK/JNK pathway (Hibi et al, 1993; Derijard et al, 1994; Kyriakis et al, 1994; Han et al, 1994). Our results indicated that signaling through SAPK/JNK cascade in Rat1 cells can also be influenced by withdrawal of serum in combination with deregulated Ras via a yet to be identified mechanism. Unlike the rapid activation (minutes to hours) by several well studied SAPK/JNK inducers such as UV irradiation and proinflammatory cytokines, induction of SAPK/JNK after serum reduction in Rat1-Ras cells was a much slower and more persistent response. It is likely that the low-serum dependent activation of SAPK/JNK may be mediated by molecular steps that are different from those responding to UV or inflammatory cytokines, and may involve SAPK/JNK activator(s) or inhibitor(s) whose regulation was altered by deregulated Ras-pathway. It is interesting to speculate that if SAPK/JNK indeed participates in critical steps of apoptosis in cells expressing deregulated Ras, then selective modulation of this cascade by Ras action may provide a molecular basis for elevated susceptibility to apoptosis in Ras-transformed cells. Future studies are needed to determine directly the functional relevance of SAPK/JNK in Ras-dependent apoptosis in Rat1 fibroblasts.

Proteins of the Bcl-2 family play important roles in regulating apoptosis. High level expression of $\mathrm{Bcl}-2$ has been found in several types of human cancer and contributes to tumorigenesis by preventing apoptosis (Tsujimoto et al, 1985; Vaux et al, 1988). In vitro, Bcl-2 has been shown to inhibit apoptosis induced by diverse stimuli (Vaux et al, 1988; Korsmeyer, 1992; Boise et al, 1993; Reed, 1994). The p21 Bax protein has been postulated to be a positive modulator of apoptosis by sequestering $\mathrm{Bcl}-2$ in $\mathrm{Bcl}-2 / \mathrm{Bax}$ heterodimers (Oltvai et al, 1993). Recently, an isoform of Bax, p18 Bax, was detected in B-cell chronic lymphocytic leukemia cells that were induced for apoptosis by a camptothecin related drug (Thomas et al, 1996), and this p18 Bax was absent in drugresistant cells. We have observed that overexpression of $\mathrm{H}$ Ras $^{R 12}$ in Rat1-Ras cells caused a marked increase of basal expression of p18 Bax. However, accumulation of p18 Bax occurred in both tetracycline-treated and -untreated Rat1-Ras cells after exposure to low-serum, which apparently did not correlate with the status of apoptosis. Low-serum stress caused a moderate increase of p21 Bax in apoptotic Rat1-Ras cells. It remains to be determined whether elevated basal expression of p18 bax or low-serum induced increase of p21 Bax in Rat1-Ras cells contributes to apoptosis.

A new observation from this study is a specific connection between Ras-dependent apoptosis and induction of two isoform(s) of Bcl-x or novel gene product(s) that are highly homologous to $\mathrm{Bcl}-\mathrm{x}$. The $\mathrm{Bcl}-\mathrm{x}$ gene has previously been shown to encode two proteins, $B c l-x_{L}$ $(30 \mathrm{kDa})$ and $\mathrm{Bcl}-\mathrm{x}_{\mathrm{S}}(21 \mathrm{kDa})$, as a result of alternative RNA splicing (Boise et al, 1993). While Bcl- $x_{\mathrm{L}}$ can inhibit apoptosis (Boise et al, 1993; Dole et al, 1995; Schott et al, 1995), overexpression of $\mathrm{Bcl}-\mathrm{x}_{\mathrm{S}}$ by $\mathrm{cDNA}$ expression vector restores apoptosis in the presence of Bcl-2. Furthermore, transfected $\mathrm{Bcl}-\mathrm{x}_{\mathrm{S}}$ induces apoptosis in cultured human tumor cells (Clarke et al, 1995; Sumantran et al, 1995). The two proteins detected by $\mathrm{Bcl}-\mathrm{x}$ antibodies in apoptotic Rat1Ras cells had apparent molecular mass of $15 \mathrm{kDa}$ and $18 \mathrm{kDa}$. Although the sequence for the p15 and p18 proteins have not been determined, our observations suggested that these protein species may be derived from the $\mathrm{Bcl}-\mathrm{x}_{\mathrm{S}}$ described previously or from new isoform(s) of $\mathrm{Bcl}-\mathrm{x}$. Our data support a role for p15 and p18 Bcl- $\mathrm{x}_{S}$ in Ras-dependent apoptosis in Rat1 cells. To our knowledge, these results provided the first experimental evidence that 
during the induction of Ras-dependent apoptosis, the level of cellular $\mathrm{Bcl}-\mathrm{x}_{\mathrm{S}}$ or related isoform(s) is specifically induced. These observations support the previous hypothesis that $\mathrm{Bcl}-\mathrm{x}_{\mathrm{S}}$ may function as an apoptosis inducer. It has been suggested that the ratios of $\mathrm{Bcl}-\mathrm{x}_{\mathrm{L}} / \mathrm{Bcl}-\mathrm{x}_{\mathrm{S}}$ or $\mathrm{Bcl}-2 /$ $\mathrm{Bcl}-\mathrm{x}_{\mathrm{S}}$ may be critical for induction of apoptosis. It is possible that elevated p15 and p18 Bcl- $x_{S}$ in Rat1-Ras cells may alter the balance between these heterodimers. Consistent with this prediction, high levels of $\mathrm{Bcl}-2$ in $\mathrm{H}$ ras-transformed 10T1/2 cells (Fernandez et al, 1994) and in $R$-Ras-overexpressing 32D cells (Wang et al, 1994) inhibit apoptosis, perhaps by establishing a new balance between heterodimers that favors cell survival.

The findings of this study support the notion that elevated susceptibility to apoptosis is an intrinsic feature of transformed cell types expressing deregulated oncogenes such as Myc and Ras. Oncogenic Ras mutations have been found in many types of human cancer. In vitro, Ras alone is not capable of transforming primary cells, and cooperation by other cellular or viral oncogenes with Ras for transformation of a variety of primary cells has been well documented (Weinberg, 1989; Marshall, 1991). The functional connection between Ras and cellular apoptosis strongly suggests that deregulated Ras oncogene can also cooperate with apoptosis modulators. Genetic alterations in tumors such as loss of p53 tumor suppressor, or elevated expression of death suppressors $\mathrm{Bcl}-2$ or $\mathrm{Bcl}-\mathrm{x}_{\mathrm{L}}$ may cooperate with Ras in tumorigenesis. In this regard, oncogenic $\mathrm{H}$-Ras has been shown to transform primary embryo fibroblasts that lack p53 tumor suppressor or transcription factor IRF-1 presumably by inhibiting H-Rasinduced apoptosis (Tanaka et al, 1994). Our results present a beginning for elucidating the molecular changes that may modulate apoptosis in tumor cells with deregulated Ras oncogene. Furthermore, since apoptosis in tumor cells is likely a process that can be both positively and negatively regulated by many cancer genes, a better understanding of the molecular events influenced by these gene products may have important implications for cancer therapy.

\section{Materials and Methods}

\section{Plasmid constructions}

Full-length $\mathrm{H}$-Ras ${ }^{\mathrm{R} 12}$ cDNA was kindly provided by Dr Geoffrey Cooper (Dana Farber Cancer Institute, Boston, MA). The pTetO-HRas $^{\mathrm{R} 12}$ was constructed by inserting full-length $\mathrm{H}$-Ras ${ }^{\mathrm{R} 12}$ cDNA into the BamHI site of PUHG10-3 (Gossen and Bujard, 1992). The pUHDTetR-VP16/Neo (pTetR-VP16/Neo) was constructed by inserting a $\mathrm{Xhol} / \mathrm{Sall}$ fragment containing the neomycin resistance gene $\left(\mathrm{NeO}^{R}\right)$ cassette from pMC1Neo/PA (Stratagene, La Jolla, CA) into the Xhol site of PUHD15-1 which contains the CMV-TetR-VP16 (Gossen and Bujard, 1992).

\section{Cell culture and generation of stable cell lines}

Rat1 cells (kindly provided by $\mathrm{Dr}$ Michael Newman, Sandoz Pharmaceuticals, East Hanover, NJ) were cultured in Dulbecco's Modified Eagle's medium (DMEM) containing 10\% fetal bovine serum (FBS) (BioWhittaker, Walkersville, $\mathrm{MD}$ ) at $37^{\circ} \mathrm{C}$ containing $5 \% \mathrm{CO}_{2}$.
Rat1/TetO-H-Ras ${ }^{\mathrm{R} 12}$ (Rat1-Ras) stable cell lines were constructed by cotransfections of pTetO-H-Ras ${ }^{\text {R12 }}$ and pUHDTetR-VP16/Neo into Rat1 cells by electroporation $(0.3 \mathrm{kV} / 500 \mu \mathrm{F})$. Transfected cells were selected for neomycin resistance by exposure to $1.0 \mathrm{mg} / \mathrm{ml}$ Geneticin (Gibco-BRL, Grand Island, NY) in complete media for 2-3 weeks. Neomycin-resistant $\left(\mathrm{Neo}^{\mathrm{R}}\right)$ colonies were cloned, expanded, and analyzed for stable, and tetracycline-repressible expression of $\mathrm{H}$ $\operatorname{Ras}^{R 12}$ by immunoblotting. Established Rat1-Ras cell lines were cultured in the same growth media. In the experiments where Rat1Ras (+Tet) cells were used, Rat1-Ras cells were pretreated with $2 \mu \mathrm{M}$ tetracycline for at least 5-7 days to suppress H-Ras ${ }^{\mathrm{R} 12}$ phenotype before experiments were initiated.

\section{Soft agar colony assay}

Rat1-Ras cells were tested for ability to grow in semisolid (soft agar) culture. Assays were performed in 24-well culture dish. The wells were pre-plated with $0.5 \mathrm{ml}$ of bottom media containing $0.8 \%$ agar. Cells (not pretreated with tetracycline) were mixed with top layer media containing $0.4 \%$ agar, and plated at 2000 cells per well in $0.5 \mathrm{ml}$ with or without $10 \mu \mathrm{M}$ tetracycline (Sigma Chemicals, St Louis, MO). Cells were incubated for $12-14$ days without refeeding. Colonies from each well were counted using a computerized image analyzer (KS400, Kontron Elektronnik) and average values were derived from measurements of $6-12$ replicate wells.

\section{Cell death or survival measurements}

Rat1-Ras cells (+/ - Tet) were seeded at low density in 12-well $\left(2 \times 10^{4}\right.$ cells/well) or 6 -well $\left(5 \times 10^{4}\right.$ cells/well) dishes in DMEM with $10 \%$ serum. Culture medium was removed $24-36 \mathrm{~h}$ later and replaced with DMEM containing $0.1 \%$ serum. At time zero, and at various times after reduction of serum concentration, culture supernatants were removed and the cells were washed once with pre-warmed PBS. Adherent cells were trypsinized, and viable cells were counted by the method of trypan-blue exclusion. Cell survival data were derived from replicate wells within the same experiment. In separate experiments, apoptosis caused by low-serum stress was documented by phase and fluorescence microscopy after staining cells with $1 \mu \mathrm{g} / \mathrm{ml}$ bisbenzimide H33258 (Sigma Chemicals).

\section{DNA fragmentation}

Rat1-Ras cells (+/ - Tet) were seeded in 6-well dishes, and exposed to DMEM with $0.1 \%$ serum as described above. At time zero or 3 days after low-serum addition, all cells (adherent and floating) were collected and lysed in $0.5 \mathrm{ml}$ of lysis buffer containing $10 \mathrm{mM}$ Tris (pH 8.0), $100 \mathrm{mM} \mathrm{NaCl}, 25 \mathrm{mM}$ EDTA, $0.5 \%$ SDS, $100 \mu \mathrm{g} / \mathrm{ml}$ proteinase $\mathrm{K}$. The lysates were incubated at $55^{\circ} \mathrm{C}$ for $4-12 \mathrm{~h}$. After sequential extractions with an equal volume of phenol $(1 \times)$, and phenol:chloroform $(1 \times)$, DNA was precipitated with ethanol, collected by centrifugation, and resuspended in TE buffer containing $10 \mathrm{mM}$ Tris $(\mathrm{pH} 7.5), 1 \mathrm{mM}$ EDTA, $1 \mu \mathrm{g} / \mathrm{ml}$ RNase A. DNA samples were fractionated by electrophoresis in a 2.0\% TAE-agarose gel and visualized by ethidium bromide staining.

\section{Western blotting and Immunoprecipitation}

Unless otherwise mentioned, for all experiments involving apoptosis, lysates were prepared from total cell population collected from both adherent and floating cells. For immunoblotting analysis, cells grown in 6-well tissue culture dishes were lysed in a buffer containing $10 \mathrm{mM}$ 
HEPES ( $\mathrm{pH}$ 7.5), $150 \mathrm{mM} \mathrm{NaCl}, 0.25 \% \mathrm{NP}-40,1 \mathrm{mM}$ sodium vanadate, $1 \mathrm{mM} \mathrm{NaF}, 10 \mu \mathrm{g} / \mathrm{ml}$ 4-(2-Aminoethyl)-benzenesulfonyl fluoride hydrochloride (AEBSF) and $10 \mu \mathrm{g} / \mathrm{ml}$ aprotinin, centrifuged at $12000 \times g$ for $20 \mathrm{~min}$ at $4{ }^{\circ} \mathrm{C}$ to collect cleared lysates, and protein concentrations determined (Bio-Rad Laboratories). Equal amounts $(50-100 \mu \mathrm{g})$ of protein were resolved by $10-15 \%$ SDS-polyacrylamide gel electrophoresis (SDS-PAGE), and were transferred to nitrocellulose by electroblotting. Immunoblots were probed with panRas antibody (Ab-1, Oncogene Science, OP21). Antibodies for ERK (06-182), p54-SAPK/JNK (06-425) were purchased from Upstate Biotechnology Inc. (UBI) (Lake Placid, NY). Antibodies for p46-SAPK/ JNK (SC-474), p38 MAPK (SC-535, 728) and Bax (SC-526) were purchased from Santa Cruz Biotechnology (Santa Cruz, CA). Bcl-x immunoblots were probed with anti- $\mathrm{Bcl}-\mathrm{x}$ monoclonal antibody (Transduction Lab, 22620). Following primary antibody blotting, immunoblots were treated with anti-mouse horseradish peroxidase (HRP)-conjugated antibody (1:5000 dilution) and developed using enhanced chemiluminescence (ECL) (Amersham Life Science).

Cell lysates prepared from low-serum treated Rat1-Ras clone 29 were separately immunoprecipitated using two anti-Bcl-x polyclonal antibodies (Transduction Lab., 22630 or Santa Cruz, SC-634), and resulting immunocomplexes were then isolated on protein $A$ Sepharose (Pharmacia Biotech Inc., Piscataway, NJ). Subsequent steps were carried out as described above for Western blot analysis.

\section{Kinase assays}

Cell lysates were prepared from total cell population (adherent and floating) are various hours after low-serum stress. Equal amounts $(200 \mu \mathrm{g})$ of protein were subjected to immunoprecipitation with polyclonal antibodies raised against p46 SAPK (Santa Cruz, SC474), p54 SAPK (Santa Cruz, SC-527), p38 MAPK (Santa Cruz, SC728), and ERK (UBI, 06-182). The p46/p54 SAPK/JNK, p38 MAPK or ERK activity was measured in an immunocomplex kinase assay with GST-C-Jun (1-79) (Stratagene), Phas I (Stratagene) or myelin basic protein (MBP) (UBI) as substrates, respectively, following previously established method (Raingeaud et al, 1995). Briefly, the immunocomplexes were washed twice with kinase buffer containing $40 \mathrm{mM}$ HEPES (pH 8.0), $20 \mathrm{mM} \mathrm{MgCl}_{2}, 0.1 \mathrm{mM}$ EGTA, $1 \mathrm{mM}$ DTT, $100 \mu \mathrm{M}$ sodium vanadate. The assays were initiated by addition of $5 \mu \mathrm{g}$ of substrate protein and $5 \mu \mathrm{M}$ ATP containing $\left[\gamma^{32} \mathrm{P}\right] \mathrm{ATP}(2 \mu \mathrm{Ci})$ in a final volume of $30 \mu \mathrm{l}$. The reactions were terminated after $30 \mathrm{~min}$ at $30^{\circ} \mathrm{C}$ by addition of Laemmli sample buffer. Phosphorylation of the substrate proteins was examined after SDS-PAGE by autoradiography.

\section{Acknowledgements}

We thank Dr Geoffrey Cooper for providing the Ha-Ras ${ }^{\mathrm{R} 12}$ cDNA, Dr Michael Newman for Rat1 cells, Wei-guo Zhang and Rick Roncinske for technical assistance.

\section{References}

Barbacid M (1987) Ras genes. Annu. Rev. Biochem. 56: 779-827 Barbacid M (1990) Ras oncogenes: their role in neoplasia. Eur. J. Clin. Invest. 20: 225-235

Boise L, Gonzalez-Garcia M, Postema C, Ding L, Lindsten T, Turka L, Mao X, Nunez $\mathrm{G}$ and Thompson C (1993) Bcl-x, a Bcl-2 related gene that functions as a dominant regulator of apoptotic cell death. Cell 74:597-608

Bos JL (1989) Ras oncogenes in human cancer. Cancer Res. 49: 4682-4689

Chen CY and Faller DV (1995) Direction of p21-ras-generated signals towards cell growth or apoptosis is determined by protein kinase $\mathrm{C}$ and $\mathrm{Bcl}-2$. Oncogene 11 : $1487-1498$
Chen Y, Meyer C and Tan T-H (1996) Persistent activation of c-Jun N-terminal kinase 1 (JNK1) in $\gamma$ radiation-induced apoptosis. J. Biol. Chem. 271: 631-634

Chen YR, Wang X, Templeton D, Davis RJ and Tan TH (1996) The role of C-Jun Nterminal kinase (JNK) in apoptosis induced by ultraviolet $C$ and $\gamma$ radiation. J. Biol. Chem. 271: 31929-31936

Clarke M, Apell, Benedict M, etal (1995) A recombinantbcl- $x_{S}$ adenovirus selectively induces apoptosis in cancer cells but not in normal bone marrow cells. Proc. Natl. Acad. Sci. USA 92: 11024-11028

Cobb M and Goldsmith E (1995) How MAP kinases are regulated. J. Biol. Chem. 270: $14843-14846$

Cuvillier O, Pirianov G, Kleuser B, Vanek P, Coso O, Gutkind S and Spiegel S (1996) Suppression of ceramide-mediated programmed cell death by sphingosine-1phosphate. Nature: $381,800-803$

Debbas M and White E (1993) Wild-type p53 mediates apoptosis by E1A. Genes \& Dev. 7: $546-554$

Derijard B, Hibi M, Wu I-H, Barrett T, Su B, Deng T, Karin M and Davis R (1994) JNK1, a protein kinase stimulated by UV light and Ha-Ras that binds and phosphorylates the c-Jun activation domain. Cell 76: 1025-1037

Dole M, Jasty R, Cooper M, Thompson C, Nunez G and Castle V (1995) Bcl- $x_{L}$ is expressed in neuroblastoma cells and modulates chemotherapy-induced apoptosis. Cancer Res. 55: 2576-2581

Evan GI, Wyllie AH, Gilbert CS, Littlewood TD, Land H, Brooks M, Waters CM, Penn LZand Hancock DC (1992) Induction of apoptosis in fibroblasts by c-myc protein Cell 69: $119-128$

Fernandez A, Marin MC, McDonnell T and Ananthaswamy HN (1994) Differential sensitivity of normal and Ha-ras-transformed $\mathrm{C} 3 \mathrm{H}$ mouse embryo fibroblasts to tumor necrosis factor: induction of Bcl-2, c-myc, and manganese superoxide dismutase in resistant cells. Oncogene 9: 2009-2017

Fernandez A, Fosdick L, Marin M, Diaz C, McDonnell T, Ananthaswamy $\mathrm{H}$ and McConkey D (1994) Differential regulation of endogenous endonuclease activation in isolated murine fibroblast nuclei by ras and bcl-2. Oncogene 10: $769-774$

Gossen M and Bujard H (1992) Tight control of gene expression in mammalian cells by tetracycline-responsive promoters. Proc. Natl. Acad. Sci. USA 89: 55475551

Greenwald I and Rubin GM (1992) Making a difference: the role of cell-cell interactions in establishing separate identities for equivalent cells. Cell 68:271281

Han J, Lee J, Bibbs L and Ulevitch R (1994) A MAP kinase targeted by endotoxin and hyperosmolarity in mammalian cells. Science 265: 808-811

Henkemeyer M, Rossi D, Holmyard D, Puri M, Mbamalu G, HarpalK, Shih TS, Jacks T and Pawson T (1995) Vascular system defects and neuronal apoptosis in mice lacking Ras GTPase-activating protein. Nature 377: 695-701

Hibi M, Lin A, Smeal T, Minden A and Karin M (1993) Identification of an oncoprotein and UV-responsive protein kinase that binds and potentiates the c-Jun activation domain. Genes \& Dev. 7: 2135-2148

Jimenez B, Arends M, Esteve P, Perona R, Sanchez R, Cajal SR, Wyllie A and Lacal JC (1995) Induction of apoptosis in NIH3T3 cells after serum deprivation by overexpression of rho-p21, a GTPase protein of the Ras superfamily. Oncogene 10: $811-816$

Karin M (1995) The regulation of AP-1 activity by mitogen-activated protein kinases. J. Biol. Chem. 270: 16483-16486

Kauffmann-Zeh A, Rodriguez-Viciana P, Ulrich E, Gilbert C, Coffer P, Downward J and Evan G (1997) Suppression of C-Myc-induced apoptosis by Ras signaling through PI(3)K and PKB. Nature 385: 544-548

Kinoshita T, Yokota T, Arai K and Miyajima A (1995) Regulation of Bcl-2 expression by oncogenic Ras protein in hematopoietic cells. Oncogene 10: 2207-2212

Korsmeyer SJ (1992) Bcl-2 initiates a new category of oncogenes. Blood 80: 879 886

Kyriakis J, Banerjee P, Nikolakaki E, Dai T, Rubie E, Ahmad M, Avruch J and Woodgett J (1994) The stress-activated protein kinase subfamily of C-Jun kinases. Nature 369: 156-160

Lowe SH and Ruley HE (1993) Stabilization of the p53 tumor suppressor is induced by adenovirus $5 \mathrm{E} 1 \mathrm{~A}$ and accompanies apoptosis. Genes \& Dev. 7: 535-545

Marcu K, Bossone S and Patel A (1992) Myc function and regulation. Annu. Rev. Biochem. 61: 809-860

Marshall CJ (1991) Tumor suppressor genes. Cell 64: 313-326

McCormick F (1995) Ras signaling and NF1. Curr. Opin. Genet. Dev. 5: 51-55 
Oltvai ZN, Milliman CL and Korsmeyer SJ (1993) Bcl-2 heterodimerizes in vivo with a conserved homolog, Bax, that accelerates programmed cell death. Cell 74 609-619

Qin XQ, Livingston DM, Kaelin WG and Adams P (1994) Deregulated transcription factor E2F-1 expression leads to S-phase entry and p53-mediated apoptosis. Proc. Natl. Acad. Sci. USA 91: 10918-10922

RaingeaudJ, Gupta S, Rogers SJ, Dickens M, Han J, Ulevitch RJ and Davis RJ (1995) Pro-inflammatory cytokines and environmental stress cause p38 mitogenactivated protein kinase activation by dual phosphorylation on tyrosine and threonine. J. Biol. Chem. 270: 7420-7426

Rak J, Mitushashi Y, Erdos V, Huang S, Filmus J and Kerbel R (1995) Massive programmed cell death in intestinal epithelial cells induced by three-dimensional growth conditions: suppression by mutant $\mathrm{c}-\mathrm{H}$-ras oncogene expression. J. Cell Biol. 131: 1587-1598

Reed JC (1994) Bcl-2 and the regulation of programmed cell death. J. Cell. Biol. 124: $1-6$

Schott A, Apel I, Nunez G and Clarke M (1995) Bcl-_ protects cancer cells from p53mediated apoptosis. Oncogene 11: 1389-1394

Shi Y, Glynn JM, Guilbert LJ, Cotter TG, Bissonnette RP and Green DR (1992) Role of c-myc in activation-induced apoptotic cell death in T cell hybridomas. Science 257: $212-214$

Sumantran V, Ealovega M, Nunez G, Clarke M and Wicha M (1995) Overexpression of Bcl- $x_{S}$ sensitizes MCF-7 cells to chemotherapy-induced apoptosis. Cancer Res. 55: 2507-2510

Tanaka N, Ishihara M, Kitagawa M, Harada H, Kimura T, Matsuyama T, Lamphier MS, Aizawa S, Mak TW and Taniguchi T (1994) Cellular commitment to oncogeneinduced transformation or apoptosis is dependent on the transcription factor IRF1. Cell $77: 829-839$
Terada K, Kaziro Y and Satoh T (1995) Ras is not required for the interleukin 3induced proliferation of a mouse pro-B cell line, BaF3. J. Biol. Chem. 270: $27880-27886$

Thomas A, Rouby S, Reed J, Krajewski S, Silber R, Potmesil M and Newcomb E (1996) Drug-induced apoptosis in B-cell chronic lymphocytic leukemia: relationship between p53 gene mutation and bcl-2/bax proteins in drug resistance. Oncogene 12: 1055-1062

Tsujimoto Y, Cossman J, Jaffe E and Croce C (1985) Involvement of the Bcl-2 gene in human follicular lymphoma. Science 228: 1440-1443

Vaux D, Cory S and Adams J (1988) Bcl-2 gene promotes hematopoietic cell survival and cooperates with c-myc to immortalize pre-B cells. Nature 335: 440-442

Verheij M, Bose R, Lin X, Yao B, Jarvis B, Grant S, Birrer M, Szabo E, Zon L, Kyriakis J, Haimovitz-Friedman A, Fuks Z and Kolesnick R (1996) Requirement for ceramide-initiated SAPK/JNK signaling in stress-induced apoptosis. Nature 380: $75-79$

Wang HG, Millan JA, CoxAD, Der CJ, Rapp UR, Beck T, Zha Hand Reed JC (1995) RRas promotes apoptosis caused by growth factor deprivation via a Bcl-2 suppressible mechanism. J. Cell Biol. 129: 1103-1114

Weinberg RA (1989) Oncogenes, antioncogenes, and the molecular basis of multistep carcinogenesis. Cancer Res. 49: 3713-3721

Wu X and Levine A (1994) p53 and E2F-1 cooperate to mediate apoptosis. Proc. Natl. Acad. Sci. USA 91: 3602-3606

Xia Z, Dickens M, Raingeaud J, Davis R and Greenberg M (1995) Opposing effects of ERK and JNK/p38 MAP kinases on apoptosis. Science 270: 1326-1331 